\title{
Biodiversity of fishery resources of the cross river system: implication for conservation and management
}

\begin{abstract}
This study aimed to assessing the biodiversity of fishery resources of the Cross River System with implication for conservation and management. Sampling was carried out once a month for twelve months (January to December, 2016) with fish gears such as cast net, drift net, gill net, local traps and hook and line. Twenty six genera of fish were identified belonging to 22 families consists of 22703 individuals collected from all the stations. The most dominant families were Clupeidae and Cichlidae with respective relative abundance of $17.69 \%$ and $13.16 \%$ while the family Osteoglossidae was the least contributing only $0.77 \%$ to the fish taxa. For seasonal distribution, Mugilidae, Clariidae, Cichlidae, Gobiidae and Sciaenidae were abundant in both wet and dry seasons while Clupeidae, Bathyclupeidae, Carangidae and Sphyraenidae were low in wet season but high in dry season. There was no significant seasonal difference $(p>0.05)$ in fish biodiversity and abundance. Like other water bodies in the Niger Delta, the Cross River system was found to possess desired potential for fisheries exploitation considering its high fish species diversity, composition and abundance. Although pollution level was not measured in this study, the continuous discharge of wastes/ effluents into the aquatic ecosystem may pose deleterious effect on the biodiversity and abundance of the resident biota. Therefore to ensure sustainable biodiversity, conservation and management of fishery resources, there is need for stringent regulation and prevention of untreated wastes/effluents discharged from households, farms and industries into the aquatic environment.
\end{abstract}

Keywords: Biodiversity, Fishery Resources, Cross River System, Conservation, Management
Volume 6 Issue 3 - 2017

\author{
Paul J Udo, Opeh Patience Bassey \\ Fisheries and Aquaculture Unit, Institute of Oceanography, \\ University of Calabar, Nigeria
}

Correspondence: Paul J Udo, Fisheries and Aquaculture Unit, Institute of Oceanography, University of Calabar, Nigeria, Email udo.paul200।@gmail.com

Received: August 29, 2017 | Published: September 12, 2017

\section{Introduction}

Inland fisheries are commercially important and a source of livelihood to many Africans including Nigerians and other subSaharan Africans. Freshwater fish contribute a substantial portion of animal protein in the diets of coastal dwellers. They provide job opportunities to artisanal fishermen and women living near the coast who actively participate in fish processing and marketing as a livelihood support. ${ }^{1}$

The growing population densities and reducing means of livelihood have forced many people into fishing therefore increasing pressure on inland fish resources. As fishing effort increases, fish fauna assemblages are significantly impacted by continuously eliminating the larger individuals and species from the multispecies communities and replacing them with smaller ones. ${ }^{2}$ Consequently, these smaller individuals are more vulnerable to poor water quality as posed by different anthropogenic activities that take place within the coastal region. Pollution of water bodies through incessant oil spills, discharge of untreated domestic and industrial effluents as well as indiscriminate dumping of wastes and drainage from farmlands, mechanic workshops and motor parks has been well noted in riverine areas of the Niger Delta. ${ }^{3}$

Threats to biodiversity, including over-exploitation through use of destructive gears, reduced water quality and quantity and other activities that can promote extensive loss of habitat if not urgently addressed can undermine biodiversity conservation and pose serious fisheries sustainability issues. Therefore, sustainable exploitation, conservation and management require knowledge of the fish species composition of the river system; hence this study on biodiversity of fishery resources of the Cross River System.

The Cross River system is a network of rivers and their tributaries in the Cross River basin. Major rivers that makeup the system include Itu River, Calabar River, Great Kwa River and Akpa Yafe River. The area is located between latitudes $4^{\circ} 30^{\prime} \mathrm{N}$ and $7^{\circ} 15^{\prime} \mathrm{N}$ and longitudes 7o30' $\mathrm{E}$ and $9^{\circ} 30^{\prime} \mathrm{N}$ (Figure 1). The climate of the area is influenced by the north-south movement of a zone of discontinuity between maritime (Atlantic) and dry continental (Sahara) air masses. The regular movement of these air masses creates distinct dry and wet seasons in the area; while the change from dry to wet season is gradual, the change from wet to dry is sharper.

The area has warm humid climate condition with maximum temperature between $26-28^{\circ} \mathrm{C}$ and mean annual rainfall of $362.5 \mathrm{~mm}$. The climate is characterized by two seasons; rainy season (April October) and dry season (November - March) ${ }^{4}$ It is also a very high productive system in terms of fish catch supporting a wide variety of shell and fin fishes. ${ }^{5}$ The mean annual fish catch from the artisanal fisheries of this system within Nigeria had been estimated at 65,000 tones $(\mathrm{t})$ making it one of the most productive of the medium size river systems in tropical Africa. ${ }^{1}$

\section{Fish sampling procedure}

Fish sampling took place at four landing sites (Ikang, Idundu, Nsidung and Itubeaches) in Akpa Yafe River, Great Kwa River, Calabar River and Itu River respectively. Sampling was carried out for twelve months between January and December, 2016. Fish samples were 
bought monthly from artisanal fishermen as they arrive at the beach and immediately transported on ice to the Institute of Oceanography central laboratory, where they were identified and preserved in $10 \%$ formalin for further examination. The fishes were identified following the provision of FAO (2001). After identification, each fish species were counted and recorded accordingly for biodiversity estimation.

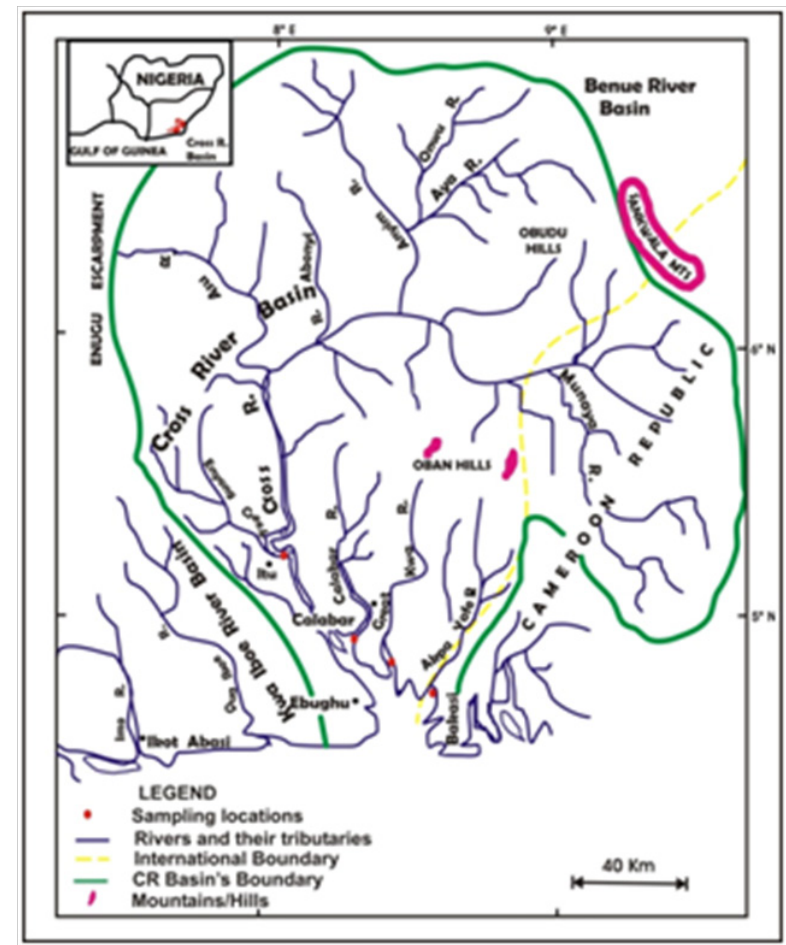

Figure I Map of Cross River Basin showing sampling stations.

\section{Estimation of biodiversity}

Biodiversity of fish species sampled from the Cross River system was estimated using Margalef's index of species richness expressed as:

$$
d=\frac{S-1}{\operatorname{In}(N)}
$$

where;

$\mathrm{S}=$ number of species in samples.

$\mathrm{N}=$ total number of individuals in the sample and ' $I n$ ' is the natural logarithm ${ }^{6}$

\section{Results and discussion}

The Numerical abundance and percentage composition of various fish taxa sampled at four different sampling stations (Akpa Yafe, Great Kwa River, Calabar River and Itu River) is presented in Table 1 while Figure 2 shows the percentage composition of fish fauna of Cross River system.

Mugilidae (5.91\%),Sciaenidae (4.07\%), Claroteidae (5.43\%), Bathyclupeidae (1.77\%), Clariidae (7.06\%), Cithannidae (4.76\%), Elopidae (1.58\%), Eleotidae (2.18\%) and Cynoglossidae (3.88\%) families were respectively represented by single species such as Mugil cephalus, Pseudodolithuselongatus, Chrysichthys nigrodigitatus, Bathygobis soporator, Clarias gariepinus, Citharinuscitherus, Eloplacerta, Eleotrisdaganensis and Cynoglossus senegalensis. Carangidae (3.35\%) were represented by Caranx hippos and Caranxlatus, Clupeidae (17.69\%) by Ethmalosa fimbriata, Ilishaafricana, and Pellonula sp., Cichlidae (13.16\%) by Orechromis niloticus and Chromidotilapia sp. Other families such as Periophthalmidae (3.96\%),Hepsetidae (2.64\%), Osteoglossidae $(0.77 \%)$, Mastacemblidae (2.08\%), Mondactylidae (2.47\%), Mormyridae (5.23\%), Mochokidae (3.22\%), Polynemidae (3.66), Schilbeidae (3.43\%), and Sphyraenidae(1.69\%) were also respectively represented by single fish species including Periophthalmus sp., Hepstusodoe, Heterotis niloticus, Mastacemoelusloennbergii, Monodactylussebae, Gnathonemus senegalensis, Synodontiseupterus, Polydactylusquadrafilis, Schilbemystus and Sphyraena barracuda.

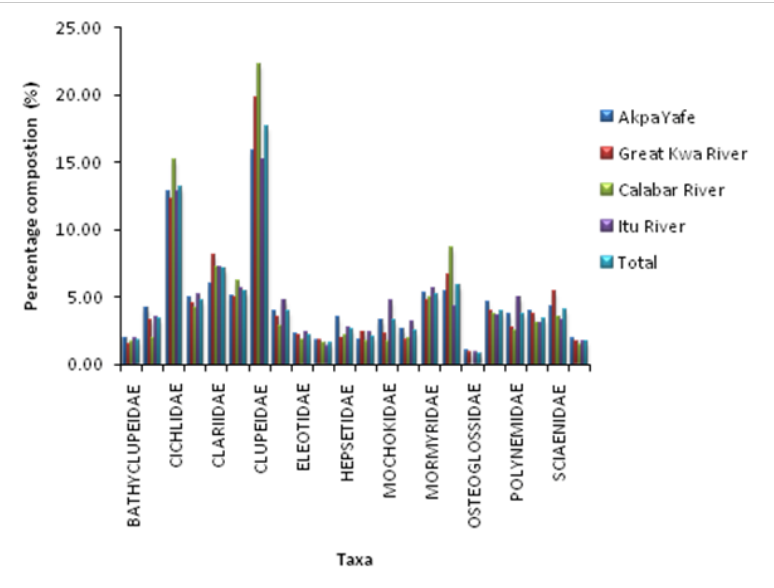

Figure 2 Percentage composition of fish fauna in Cross River System.

Results of the present study reveal twenty six genera which were identified from all the stations and they belong to 22 families made of 22703 individuals. Similar finding was observed in NtakInyang Stream, Akwa Ibom State by Onuoha et al. ${ }^{7}$ who recorded 26 fish species belonging to 20 families. However, Sikoki et al. ${ }^{8}$ recorded lower values of 17 fish species belonging to 15 genera and 11 families in Onu-Iyiukwu stream, south eastern Nigeria. The most dominant families were Clupeidae and Cichlidae with respective relative abundance of $17.69 \%$ and $13.16 \%$ while the family Osteoglossidae was the least contributing only $0.77 \%$ to the fish taxa. Clupeidae and Cichlidae were also found to be most preponderant in all the stations and analysis of variance showed no significant disparity $(p>0.05)$ of the percentage composition of fish fauna between stations. Mugilidae, Clariidae, Cichlidae, Gobiidae and Sciaenidae had the most abundant distribution for both wet and dry seasons, while Clupeidae, Bathyclupeidae, Carangidae and Sphyraenidae were low in wet season but high in dry season but with no significant difference $(p>0.05)$ between the data recorded for both seasons.

Biodiversity of the Cross River System as indicated by species richness (Margalef's index of 2.49) was lower than that obtained from other parts of the Niger Delta region. For example Odo et al. ${ }^{9}$ recorded respective higher values of 3.19, 3.01 and 2.97 in Ogurugu, Otuocha and Nsugbe stations of the Anambra River. The low value of species richness could be due to a combined effect of natural and anthropogenic phenomena such as flooding and water pollution notable in Cross River State which may result to fish kill or migration. Flood and pollution of the aquatic ecosystem have been known to have negative effect on the distribution of the resident organisms. ${ }^{10}$ 
Table I Composition of fish species of the Cross River System

\begin{tabular}{|c|c|c|c|c|c|c|c|c|c|c|}
\hline \multirow[b]{2}{*}{ Taxa } & \multicolumn{2}{|c|}{ Akpa Yafe } & \multicolumn{2}{|c|}{ Great Kwa River } & \multicolumn{2}{|c|}{ Calabar River } & \multicolumn{2}{|c|}{ Itu River } & \multicolumn{2}{|l|}{ Total } \\
\hline & NA & (\%) & NA & (\%) & NA & (\%) & NA & $(\%)$ & Total & $(\%)$ \\
\hline Bathyclupeidae & 71 & 1.66 & 75 & $\mid .51$ & 117 & 1.89 & 139 & 1.91 & 402 & 1.77 \\
\hline Carangidae & 82 & 1.92 & 163 & 3.29 & 259 & 4.18 & 256 & 3.51 & 760 & 3.35 \\
\hline Cichlidae & 650 & 15.24 & 608 & 12.28 & 793 & 12.79 & 937 & 12.86 & 2988 & 13.16 \\
\hline Cithannidae & 178 & 4.17 & 222 & 4.48 & 305 & 4.92 & 376 & 5.16 & 1081 & 4.76 \\
\hline Clariidae & 309 & 7.24 & 402 & 8.12 & 368 & 5.94 & 524 & 7.19 & 1603 & 7.06 \\
\hline Claroteidae & 262 & 6.14 & 245 & 4.95 & 317 & 5.11 & 409 & 5.61 & 1233 & 5.43 \\
\hline Clupeidae & 948 & 22.22 & 980 & 19.79 & 984 & 15.88 & 1105 & 15.16 & 4017 & 17.69 \\
\hline Cynoglossidae & 118 & 2.77 & 175 & 3.53 & 246 & 3.97 & 343 & 4.71 & 882 & 3.88 \\
\hline Eleotidae & 75 & 1.76 & 105 & 2.12 & 143 & 2.31 & 172 & 2.36 & 495 & 2.18 \\
\hline Elopidae & 66 & 1.55 & 87 & 1.76 & 109 & 1.76 & 97 & 1.33 & 359 & 1.58 \\
\hline Hepsetidae & 91 & 2.13 & 97 & 1.96 & 215 & 3.47 & 197 & 2.7 & 600 & 2.64 \\
\hline Mastacemblidae & 72 & 1.69 & 117 & 2.36 & 113 & 1.82 & 170 & 2.33 & 472 & 2.08 \\
\hline Mochokidae & 71 & 1.66 & 113 & 2.28 & 201 & 3.24 & 346 & 4.75 & 731 & 3.22 \\
\hline Mondactylidae & 84 & 1.97 & 89 & 1.8 & 160 & 2.58 & 227 & 3.12 & 560 & 2.47 \\
\hline Mormyridae & 212 & 4.97 & 233 & 4.71 & 328 & 5.29 & 414 & 5.68 & 1187 & 5.23 \\
\hline Mugilidae & 368 & 8.63 & 327 & 6.6 & 337 & 5.44 & 309 & 4.24 & $|34|$ & 5.91 \\
\hline Osteoglossidae & 0 & 0 & 45 & 0.91 & 64 & 1.03 & 65 & 0.89 & 174 & 0.77 \\
\hline Periophthalmidae & 158 & 3.7 & 197 & 3.98 & 283 & 4.57 & 262 & 3.6 & 900 & 3.96 \\
\hline Polynemidae & 107 & 2.51 & 136 & 2.75 & 229 & 3.69 & 359 & 4.93 & 831 & 3.66 \\
\hline Schilbeidae & 132 & 3.09 & 186 & 3.76 & 242 & 3.9 & 218 & 2.99 & 778 & 3.43 \\
\hline Sciaenidae & 150 & 3.52 & 269 & 5.43 & 267 & 4.31 & 239 & 3.28 & 925 & 4.07 \\
\hline Sphyraenidae & 62 & 1.45 & 81 & 1.64 & 118 & 1.9 & 123 & 1.69 & 384 & 1.69 \\
\hline & 4266 & 100 & 4952 & 100 & 6198 & 100 & 7287 & 100 & 22703 & 100 \\
\hline
\end{tabular}

NA: Numerical Abundance; \%: Percentage Composition

Odo et al. ${ }^{9}$ documented respective higher values of 52 and 27 fish species in Anambra, and Osun rivers and lower value of 23 in Ogunriver. Sixty nine years ago in a preliminary survey of the fresh water fish of Nigeria, Welman ${ }^{11}$ reported 39 fish species in the Cross River as against 26 reported in the present study. The trend in the biodiversity of fish fauna and the sequence of changes in fish populations can be said to be complex and variable in the Niger Delta region due to climate change.

Results revealed that some families were represented by only single species while others were represented by two or three. Their relative abundance also significantly varied between species and families but did not significantly vary between stations and seasons. Low percentage composition and biodiversity index of fish fauna recorded in the study area may be attributable to point- and non- point sources of pollution in the area. Although pollution level was not measured in this study, the continuous discharge of wastes/effluents into the aquatic ecosystem may pose deleterious effect on the biodiversity and abundance of the resident biota. Therefore to ensure sustainable biodiversity, conservation and management of fishery resources, there is need for stringent regulation and prevention of untreated wastes/ effluents discharged from households, farms and industries into the aquatic environment. Also, future effort should be geared towards the investigation of the ecology/biology of the dominant species as well as rare species of the Cross River system with the view of enhancing their sustainability and conservation.

\section{Acknowledgments}

None.

\section{Conflicts of interest}

None.

\section{References}

1. Moses BS, Udoidiong OM, Okon AO. A statistical survey of the artisanal fisheries of south-eastern Nigeria and the influence of hydroclimatic factors on catch and resource productivity. Elsevier Science Direct. 2002;57(3):267-278.

2. Welcomme RI. River fisheries in Africa: their relationship to flow regimes. NAGA, World Fish Center Quarterly. 2003;26(3):22-26.

3. Asuquo FE, Udoh JP. Patterns of total hydrocarbon, copper and iron in some fish from cross river Estuary, Nigeria. West African Journal of Applied Ecology. 2002;3:91-97.

4. Ekpo IE, Obot OI, Essien-Ibok MA. Studies on the food composition and feeding pattern of fish communities in Qua Iboe River, Niger Delta region of Nigeria. American Journal of Biology and Life Sciences. 2014;2(5):122-134.

5. Nawa IG. The Abundance and Distribution of Benthos in the Cross River Estuary. A Paper Presented During the First National Workshop on Oceanography, University of Calabar, Nigeria. 1986.

6. Margalef DI. Diversidadde species en lascomunidalesnaturals Publication Institute Biological Application, Barcelona. 1949;9:5-27.

7. Onuoha GC, Ekpo I E, Chude LA, et al. Composite Preliminary Ichthyofaunal Survey of NtakInyang Stream, Ikpa River, Nigeria. Nigeria Journal Agricultural and Food Environment. 2010;6:83-89.

8. Sikoki FD, Zabbey N, Anyanwu IN. Fish Assemblages of Onu-IyiUkwu Stream in Southeastern Nigeria. Tropical Freshwater Biology. 2008; 17:41-51.

9. Odo GE, Didigwu N C, Eyo JE. The fish fauna of Anambra river basin, Nigeria:species abundance and morphometry. Rev Biol Trop. 2009;57(1-2):177-186.

10. Ogbeibu AE, Oribhabor BJ. Ecological Impact of River Impoundment Using Benthic Macro-invertebrates as Indicator. Water Research. 2002;36(10):2427-2436.

11. Welman JB. Preliminary survey of the Freshwater Fisheries of Nigeria. Government, Lagos, Nigeria. 1948. 